\title{
Understanding the Ecosystem Services of Urban Forests: Implications for Climate Change Mitigtation in the case of Adama City of Oromiya Region Sate, Ethiopia
}

Hingabu Hordofa Koricho ( $\square$ hingabuh77@gmail.com )

"Wuhan University of Technology" https://orcid.org/0000-0001-6430-5098

\section{Ararsa Derese Seboka}

Hawassa University

\section{Fekadu Fufa}

Jimma University College of Engineering and Technology: Jimma University Institute of Technology

\section{Tikabo Gebreyesus}

Hawassa University

\section{Shaoxian Song}

Wuhan University of Technology - Mafangshan Campus: Wuhan University of Technology

\section{Research}

Keywords: Urban forest, Ecosystem service, Adama trees, Carbon sequestration, Pollutant

Posted Date: December 28th, 2020

DOI: https://doi.org/10.21203/rs.3.rs-135013/v1

License: (c) (i) This work is licensed under a Creative Commons Attribution 4.0 International License. Read Full License 


\section{Abstract \\ Background}

this study was conducted to explore the ecosystem services of urban forests in Adama city, central Ethiopia. Attempts were made to quantify the carbon storage and sequestration, air pollution removal and hydrological benefits of urban trees. The urban forest stracture and composition of the city was surveyed and analyzed. The i-Tree Eco Model was employed to analyze the ecosystem services based on the current urban forests structure of the city.

\section{Results}

the result revealed that the urban trees of the Adama city stored a total of 116,000 tons of carbon. The tree species identified with higher $\mathrm{CO}_{2}$ sequestration per year were Melia azedarach (15\%), Eucalyptusglobulus (8\%, Carica papaya(7\%), and Delonix regia (6\%). Approximately 22, 12, 10 and $4 \%$ of carbon were stored by Eucalyptus globulus, Melia azedarach, Carica papaya and Delonix regia tree species respectively. Moreover, trees and shrubs spps. in the city removed about 188 thousand tons of air pollutants caused by $\mathrm{O}_{3}, \mathrm{CO}, \mathrm{NO}_{2}, \mathrm{PM} 2.5$ and $\mathrm{SO}_{2}$ per year. In Adama, 35\% of the urban trees' VOC emissions were from Eucalyptus cinerea and Eucalyptus globulus. The monetary value of Adama urban forest in terms of carbon storage, carbon

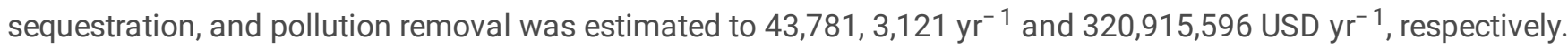

\section{Conclusions}

it was concluded that significant quantiy of $\mathrm{CO}_{2}$ and air pollutnants were found being removed by the exotic tree and shrub species. However, every plant species found in the city does not mean ecologically important due their VOC emitting nature. Thus, proper planning and inventories of urban forests should be put in place by the key stakeholders such as government, urban foresters and city dwellers as urban trees mitigates climate changes and essential to alleviate urban pollution besides the trees add esthetic value to the city.

\section{Introduction}

Human population growth and urbanization of the world have threatening the environment in various foms, such as elevated temperatures, increases air pollution and stormwater quantity, and decreases in stormwater quality, which pose major environmental and public health problems in cities (Rydin et al. 2012; Seto and Shepherd, 2009). In this regard, urban forest ecosystem plays an important role in providing multiple service and environmental benefits to urban environment (Forrest et al. 1999 ; Strohbach and Haase, 2012).

Ethiopia's urban centers have been urbanizing at rapid rate with a rate of about 4 to $5 \%$, and its urban population is expected to increase from time to time (Girma et al., 2019). The current phenomenon in Ethiopia has been associated with environmental problems in most cities. The major problems are urban sprawl, solid and liquid waste management; water, air, and noise pollution; illegal settlements and the degradation of open green areas (Mpofu, 2013). Developing countries like Ethiopia are experiencing the effects of climate change such as an increase in average temperature and change in rainfall patterns.

Urban green space is considered a mitigate interference for urban heat. While increasing the urban green space coverage is expected to reduce the urban heat, studies on the effects of urban green space formation have produced inconsistent results (Terfa et al., 2020). Quantification of ecosystem services provision by urban trees can be used to assess the actual and potential role of urban forests in providing environmental, social and economic benefits. Assessment of ecosystem services provided by the green spaces of Adama city is quiet scanty. The EU FP7 Climate change and Urban Vulnerability in Africa (CLUVA) project (www.cluva.eu) provided a foundation for the assessment of ecosystem services by the green spaces of the 
city. Apart from the above study, quantitative assessment of individual ecosystem services provided by urban forests of Adama city is generally lacking. As a result, information on ecosystem services from urban forests and green spaces are not available for use in the urban planning activities of the city.

There are several techniques and models that have been developed to quantify ecosystem services. These models include itree eco and i-tree streets (i-tree, 2010). In this work, i-tree eco suite was used for the analysis. The i-tree Eco is designed to use standardized field data from randomly located plots, as well as local hourly air pollution and meteorological data, to quantify urban forest structure, ecological function, and the associated value (Nowak et al. 2008; McPherson 2010).

Such application of technologies to explore the ecosystem services of urban forests is extraordinary in Ethiopia. So far, there is no any i-tree Eco based ecosystem services assessment study conducted in Ethiopia. Thus, the main aim of this study was to assess the ecosystem service of urban forest of Adama city interms of climate change mitigation. More specifically, the study was intended i) to assess carbon storage and sequestiration potential of adama city trees ii) to estimate the oxiygen production and pollution removal by different species of adama city trees and iii) assess the hydrological and functional values of trees in Adama city.

\section{Research Methods \\ Study Area}

This study was conducted in Adama city of Oromiya National Regional State, Central Ethiopia. Adama city is geographically situated between $8^{\circ} 32^{\prime} 24^{\prime \prime} \mathrm{N}$, latitude and $39^{\circ} 16^{\prime} 12^{\prime \prime}$ E longitude within the altitudinal range of 1,712 meter a.s.l. (Fig. 1). The total area of the city was about 13,366.5 ha and it is situated at about $99 \mathrm{~km}$ distance from Addis Ababa the capital city of Ethiopia. The annual average minimum and maximum temperature of the study area was 13 and $27^{0} \mathrm{c}$, respectively. The annual average rainfall is $837-1005.7 \mathrm{~mm}$ and its climate varies due to the great variation in altitude (Central Statistical Authority, 2007). The total population of Adama was about 303,569 of which 150,228 are males and 153,341 are females.

Figure 1: Location map of the study area.

\section{Research Design and Sampling}

The reconessance survey was conducted (from October to December, 2018) by a team of 5 people. The site assessment has done to observe the general plot information used to identify the plots and its general characteristics. In this work, trees and shrub information were used to estimate trees and shrubs leaf area/biomass, pollution removal, and volatile organic compound (VOC) emissions. Finally, tree informations used to estimate forest ecosystem value, carbon storage, carbon sequestration and hydrological functions of Adama city urban forest.

In this study, a total of 214 sample plots have established by using a simple random sampling method. As a general rule, 200 plots (one-tenth acre each) will yield a standard error of about $10 \%$ for an estimate of the entire city. As the number of plots increases, the standard error will be decrease; and therefore we were more confident to estimate for the population. With regard to the sample plot size, the standard plot size for an Eco analysis is a 0.1 -acre circular plot with a radius of $11.16 \mathrm{~m}$ or 0.0407 hectares. The samples of plots were created directly in the Eco application using the random plots generator via the Google Maps function (Fig. 2).

The diameters of all identified trees and shrubs were measured at breast height ( $1.3 \mathrm{~m}$ above ground) using a diameter tape (5 $\mathrm{m}$ length). Diameter of individual trees were recorded to calculate basal area and relative basal area of plant species. Height of all sampling trees and shrubs were measured by silva hypsometer.

The field data collection crews were typically located field plots using maps to indicate plot location. Aerial photographs and digital maps were used in order to locate plots and features. During random plots distribution in the city, the researchers faced a challenge of miss place placement of some plots; for example, some plot center has fallen in buildings, private land and the 
border of different land ownerships and land-use types; as a result the researchers professional skills were used to shift the plot center into appropriate locations.

Figure 2: Sample plots (highlighted yellow) distribution randomly within the project site based on the standard of the i-tree eco Model

\section{Data collection and analysis}

In this study, the data was collected from sample plots which have an area of 0.0407 ha $(1 / 10 \mathrm{ac})$ that randomly laid in city areas of states and data was analyzed using the i-tree Eco (formerly Urban Forest Effects (UFORE)) model (Nowak et al., 2008). The state plots were based on Forest Inventory Analysis national program plot design and data were collected as part of pilot projects testing FIA data collection in urban areas (Steenberg et al., 2016). For each tree found in the sample plots carbon storage, annual sequestration, oxygen production, pollutant removal and hydrological functions were estimated using biomass and growth equations. Inorder to carryout in national estimates of carbon storage and sequestration, the carbon data was standardized per unit of tree cover.

\section{Results}

\section{Structure of tree species of Adama city}

Trees covered about $20 \%$ of Adama city and provided 8.871 square miles of leaf area. Indeed, total leaf area is greatest in urban areas. In Adama urban trees, the most dominant species in terms of canopy cover and leaf area were Acacia albida, Casimiroa edulis, and Eucalyptus cinerea. The attributes of 20 tree species are presented in (Table 1). 
Table 1

The measuremts and condition of some twenty common tree species

\begin{tabular}{|c|c|c|c|c|c|c|c|c|c|}
\hline Species & Frequency & DBH & Height & $\begin{array}{l}\text { Canopy } \\
\text { Cover } \\
\left(\mathrm{ft}^{2}\right)\end{array}$ & $\begin{array}{l}\text { Tree } \\
\text { conditoin }\end{array}$ & $\begin{array}{l}\text { Leaf } \\
\text { area/ac }\end{array}$ & $\begin{array}{l}\text { Leaf } \\
\text { biomass(lb) }\end{array}$ & $\begin{array}{l}\text { Leaf } \\
\text { area } \\
\text { index }\end{array}$ & $\begin{array}{l}\text { Basal } \\
\text { area }\left(\mathrm{ft}^{2}\right)\end{array}$ \\
\hline $\begin{array}{l}\text { Persia } \\
\text { americana }\end{array}$ & 31 & 4.27 & 18.67 & 87.82 & Good & 318.48 & 4.887 & 3.635 & 0.12 \\
\hline $\begin{array}{l}\text { Eucalyptus } \\
\text { globulus }\end{array}$ & 28 & 17.05 & 48.74 & 102.02 & Good & 521 & 13.82 & 4.51 & 3.11 \\
\hline Citrus medica & 16 & 8.16 & 22.77 & 134.6 & Excellent & 649.72 & 17.94 & 4.23 & 0.48 \\
\hline $\begin{array}{l}\text { Podocarpus } \\
\text { falcatus }\end{array}$ & 24 & 7.46 & 33.66 & 88.525 & Good & 528.7 & 8.1 & 5.06 & 0.43 \\
\hline $\begin{array}{l}\text { Eucalyptus } \\
\text { camaldulensis }\end{array}$ & 24 & 7.87 & 86.05 & 77.43 & Excellent & 378.58 & 10.04 & 4.94 & 0.55 \\
\hline Olea europea & 11 & 5.1 & 16.4 & 26.4 & Poor & 104 & 1.6 & 3.9 & 0.1 \\
\hline $\begin{array}{l}\text { Acacia } \\
\text { abyssinica }\end{array}$ & 40 & 7.09 & 17.39 & 98.36 & Fair & 403.56 & 19.97 & 3.88 & 0.58 \\
\hline $\begin{array}{l}\text { Eucalyptus } \\
\text { grandis }\end{array}$ & 14 & 7.91 & 36.53 & 110.62 & Fair & 754.04 & 17.85 & 6.35 & 0.47 \\
\hline $\begin{array}{l}\text { Cordia } \\
\text { africana }\end{array}$ & 16 & 7.42 & 18.7 & 120.45 & Good & 554.11 & 8.50 & 3.77 & 0.38 \\
\hline $\begin{array}{l}\text { Mangifera } \\
\text { indica }\end{array}$ & 32 & 5.88 & 18.88 & 66.06 & Good & 250.85 & 3.84 & 3.75 & 0.23 \\
\hline $\begin{array}{l}\text { Melia } \\
\text { azedarach }\end{array}$ & 119 & 8.11 & 18.39 & 57.28 & Good & 247.23 & 3.78 & 3.88 & 0.57 \\
\hline Citrus sinensis & 20 & 4.04 & 13.61 & 45.6 & Good & 194.765 & 4.97 & 4.225 & 0.115 \\
\hline Carica papaya & 55 & 9.10 & 17.71 & 41.25 & Good & 160.02 & 2.44 & 3.83 & 0.89 \\
\hline Delonix regia & 33 & 10.44 & 36.13 & 150.65 & Excellent & 610.06 & 9.35 & 4.23 & 0.71 \\
\hline $\begin{array}{l}\text { Grevillea } \\
\text { robusta }\end{array}$ & 28 & 7.07 & 28.85 & 80.328 & Good & 493.57 & 12.3 & 5.38 & 0.46 \\
\hline $\begin{array}{l}\text { Eucalyptus } \\
\text { cinerea }\end{array}$ & & 8.37 & 75.68 & 179.28 & Good & 849.59 & 22.51 & 4.7 & 0.45 \\
\hline Acacia tortilis & 38 & & 16.97 & 146.07 & Fair & 536.09 & 26.54 & 3.48 & 0.27 \\
\hline $\begin{array}{l}\text { Leucaena } \\
\text { leucocephala }\end{array}$ & 35 & 4.62 & 18.05 & 50.10 & Excellent & 182.08 & 2.78 & 4.26 & 0.14 \\
\hline $\begin{array}{l}\text { Casimiroa } \\
\text { edulis }\end{array}$ & 15 & 9.12 & 30.66 & 272.33 & Good & 1272.71 & 19.51 & 5 & 0.54 \\
\hline Acacia albida & & 14.42 & 31.02 & 270.53 & Good & 1366.97 & 67.67 & 4.78 & 1.53 \\
\hline Total & & 153.57 & 604.93 & 2205.85 & & 10376.2 & 278.46 & 87.82 & 12.18 \\
\hline
\end{tabular}

\section{Carbon Storage and Sequestration}

Trees reduce the amount of carbon in the atmosphere by sequestering carbon in new growth every year. The gross carbon sequestration of Adama city trees was about 8,291 thousand tons of carbon per year with an associated value of 31,134 USD. Net carbon sequestration in the urban forest was about 7,474 thousand tons. The most common species that are known 
for the greater share of carbon sequestration in the study area forest are listed in Table 2. In particular, the tree species such as Melia azedarach, Eucalyptus globulus, Carica papaya and Delonix regia sequestered the most perecentage of carbon which were approximately $15,8,7$ and $6 \%$ of all annually sequestered carbn respectively (Fig. 3).

Figure 3: Estimated annual gross carbon sequestration (points) and value (bars) by urban tree species of Adama city

Trees in Adama urban forests were estimated to store 116,000 tons of carbon (437,994.7 USD). Of the species sampled, Eucalyptus globulus, Melia azedarach, Carica papaya and Delonix regia stored the most approximately $22,12,10$ and $4 \%$ of all stored carbn respectively (Table 2).

Table 2

Carbon storage and sequestration potential of common woody speicies of Adama urban forest.

\begin{tabular}{|c|c|c|c|c|c|}
\hline Species & $\begin{array}{l}\text { No of } \\
\text { trees }\end{array}$ & $\begin{array}{l}\text { Carbon storage } \\
\text { (ton/yr) }\end{array}$ & $\begin{array}{l}\text { Co2 } \\
\text { equivalent(ton) }\end{array}$ & $\begin{array}{l}\text { Carbon sequestratoin } \\
\text { (ton/yr) }\end{array}$ & $\begin{array}{l}\text { Co2 } \\
\text { equivalent(ton) }\end{array}$ \\
\hline Acacia abyssinica & 26099 & 6086.6 & 22319.6 & 321.3 & 1178.22 \\
\hline Acacia albida & 5872 & 3147.7 & 11542.6 & 251.39 & 921.84 \\
\hline Melia azedarach & 77643 & 14273.62 & 52341.4 & 1220.63 & 4476.04 \\
\hline $\begin{array}{l}\text { Casuarina } \\
\text { cunninghamiana }\end{array}$ & 5220 & 5544.41 & 20331.4 & 51.27 & 188.02 \\
\hline Carica papaya & 35886 & 11018.11 & 40403.4 & 607.28 & 2226.91 \\
\hline Delonix regia & 21531 & 4844.54 & 17764.9 & 518.38 & 1900.9 \\
\hline Eucalyptus cinerea & 13702 & 2260.97 & 8291 & 232.21 & 851.51 \\
\hline Eucalyptus globulus & 18269 & 25676.41 & 94155.4 & 612.23 & 2245.04 \\
\hline Ficus sur & 1957 & 986.93 & 3619.1 & 47.36 & 173.66 \\
\hline Ficus sycomorus & 3915 & 2892.47 & 10606.7 & 243.8 & 894.03 \\
\hline Ficus vasta & 652 & 5001.59 & 18340.8 & 14.98 & 54.95 \\
\hline Grevillea robusta & 18269 & 2670.2 & 1176.82 & 320.92 & 1176.82 \\
\hline Podocarpus falcatus & 15659 & 2114.66 & 952.95 & 259.87 & 952.95 \\
\hline Acacia tortilis & 24794 & 1854.2 & 6799.2 & 277.86 & 1018.91 \\
\hline Casimiroa edulis & 9787 & 1572.1 & 5765 & 217.06 & 795.96 \\
\hline Citrus medica & 10439 & 1640.8 & 6016.8 & 179.74 & 659.12 \\
\hline Ficus elastica & 4567 & 1996.3 & 7320.3 & 169.2 & 620.46 \\
\hline Persea americana & 20226 & 663.5 & 2433.1 & 138.63 & 508.34 \\
\hline Total & 314487 & 94245.11 & 330180.47 & 5684.11 & 20843.68 \\
\hline
\end{tabular}

\section{Air Pollution Removal by Urban Trees}

Urban pollution removal capacities of each urban tree species are presented in (Fig. 4). It is estimated that trees and shrubs removed 188 thousand tons of air pollution (ozone $\left(\mathrm{O}_{3}\right)$, carbon monoxide $(\mathrm{CO})$, nitrogen dioxide $\left(\mathrm{NO}_{2}\right)$, particulate matter less than 2.5 microns (PM2.5), and sulfur dioxide $\left(\mathrm{SO}_{2}\right)$ ) per year with an associated value of 686,519,156.80 USD.

Figure 4: Annual pollution removal (points) and value (bars) by urban trees of Adama city 


\section{Volatile Organic Compaound Emisson}

In 2018, trees in Adama city emitted about 51 tons of volatile organic compounds (VOCs) per year of which 34 tons was isoprene and 18 tons was monoterpenes. The amount of emissions from the trees varried based on species characteristics (e.g. some genera such as Grevellia robusta was high isoprene emitter) and amount of leaf biomass. In Adama city, 35\% of the urban trees' VOC emissions was by Eucalyptus cinerea and Eucalyptus globulus. These VOCs are precursor chemicals to ozone formation (Table 3).

Table 3

Estimates of VOC removal by common woody species of Adama city, central Ethiopia.

\begin{tabular}{|c|c|c|c|}
\hline Species Name & Monoterpene (lb/yr.) & Isoprene (lb/yr.) & Total VOCs (lb/yr.) \\
\hline Persea americana & 210.00 & 7.50 & 217.50 \\
\hline Eucalyptus globulus & 2681.90 & 13430.50 & 16112.50 \\
\hline Schinus molle & 714.10 & 0.00 & 714.10 \\
\hline Acacia torulosa & 1132.00 & 8.10 & 1140.10 \\
\hline Eucalyptus camaldulensis & 1670.40 & 8364.80 & 10035.20 \\
\hline Acacia abyssinica & 5540.80 & 39.60 & 5580.50 \\
\hline Eucalyptus grandis & 1733.20 & 8679.40 & 10412.60 \\
\hline Mangifera indica & 643.10 & 0.00 & 643.10 \\
\hline Pinus patula & 384.70 & 2.80 & 387.50 \\
\hline Citrus sinensis & 298.70 & 4.90 & 303.70 \\
\hline Acacia seyal & 489.90 & 3.50 & 493.40 \\
\hline Ficus elastica & 289.60 & 7117.60 & 7407.30 \\
\hline Grevillea robusta & 159.10 & 17.10 & 176.20 \\
\hline Eucalyptus cinerea & 3280.00 & 16425.80 & 19705.80 \\
\hline Acacia tortuosa & 772.00 & 5.50 & 777.60 \\
\hline Acacia tortilis & 6992.40 & 50.00 & 7042.50 \\
\hline Acacia albida & 4222.90 & 30.20 & 4253.10 \\
\hline Casimiroa edulis & 981.20 & 14.50 & 995.70 \\
\hline Eucalyptus globoidea & 996.40 & 4989.70 & 5986.10 \\
\hline Total & 34055.50 & 59205.70 & 93261.80 \\
\hline
\end{tabular}

\section{Hydrological benefits of urban trees}

Urban forests as a whole have important roles throughout the hydrological cycle. Tree crowns intercept rain and reduce the amount of water reaching the pervious or impervious surfaces below. This can increase evapotranpiriation and transpiration of urban forests. The total leaf area of adama urban forest was 2,298 hectarea. The potential evapotranspirtion of Adama urban forest was about $187,655,094 \mathrm{ft}^{3}$ per year, whereas the transpiration potential was estimated to $48,441,686 \mathrm{ft}^{3}$ per year. In (Table 4) presents the hydrological benefits of 18 tree species of Adama city. 
Table 4

Hydrological benefits of 18 tree species of Adama city

\begin{tabular}{|c|c|c|c|c|}
\hline Species Name & Number of Trees & Leaf Area & Potential Evapotranspiration & Transpiration \\
\hline Ficus sur & 1957 & 35.90 & 1186695.64 & 306336.14 \\
\hline Ficus vasta & 652 & 2.64 & 87181.81 & 22505.30 \\
\hline Citrus medica & 10439 & 155.71 & 5146853.39 & 1328619.70 \\
\hline Podocarpus falcatus & 15659 & 190.06 & 6282314.47 & 1621730.05 \\
\hline Eucalyptus cinerea & 13702 & 267.24 & 8833401.02 & 2280272.96 \\
\hline Casimiroa edulis & 9787 & 285.95 & 9451862.27 & 2439923.87 \\
\hline Acacia tortilis & 24794 & 305.14 & 10085969.15 & 2603613.57 \\
\hline Acacia abyssinica & 26099 & 241.79 & 7992174.74 & 2063117.02 \\
\hline Azadirachta indica & 77643 & 440.68 & 14566266.32 & 3760167.03 \\
\hline Carica papaya & 35886 & 131.83 & 4357542.49 & 1124865.31 \\
\hline Eucalyptus globulus & 18269 & 218.51 & 7222632.76 & 1864465.81 \\
\hline Grevillea robusta & 18269 & 207.00 & 6842149.76 & 1766247.12 \\
\hline Persea americana & 20226 & 147.88 & 4888111.40 & 1261827.49 \\
\hline Delonix regia & 21531 & 301.55 & 9967327.43 & 2572987.15 \\
\hline Acacia albida & 5872 & 184.28 & 6091170.63 & 1572387.77 \\
\hline Casuarina cunninghamiana & 5220 & 24.65 & 814877.96 & 210354.33 \\
\hline Ficus elastica & 4567 & 611.96 & 20227693.99 & 5221620.04 \\
\hline Ficus sycomorus & 3915 & 225.14 & 7441674.13 & 1921009.62 \\
\hline Total & 14487 & 3977.91 & 1485899.36 & 33942050 \\
\hline
\end{tabular}

\section{Eco benefit of Adama urban trees}

The summary of ecosystem value that include number of trees, carbon storage and sequestration, pollution removal, and structural value of woody species of Adama urban forest were estimated and summarized in (Table 5).

Table 5

The summary of monetery value of Adama urban trees

\begin{tabular}{|llllllllll|l|}
\hline Trees & & \multicolumn{3}{c}{ Carbon Storage } & \multicolumn{3}{c|}{ Gross Carbon Sequestration } & \multicolumn{2}{c|}{ Pollution Removal } \\
\hline No & SE & Ton & SE & USD & Ton/yr. & SE & USD/yr. & Ton/yr. & USD/yr. \\
\hline 525235 & $\pm 43,558$ & 116280 & $\pm 33,049$ & 437,691 & 8291 & \pm 845 & 31,209 & 89445 & $320,915,596$ \\
\hline \multicolumn{4}{|l}{ SE: Standard Error, USD: US Dollar yr.: year } & & & & & & \\
\hline
\end{tabular}

Carbon storage and gross carbon sequestration values were calculated based on the price of 3.76 USD per ton. Also, the pollution removal value was calculated based on the prices of 1,041.15 USD per ton (CO), 7,330.42 USD per ton $\left(\mathrm{O}_{3}\right), 7,330.42$ USD per ton $\left(\mathrm{NO}_{2}\right), 1,794.60$ USD per ton $\left(\mathrm{SO}_{2}\right), 4,894.18$ USD per ton (PM2.5).

\section{Discussions}


This study estimated the quantity of the $\mathrm{C}$ stored and sequestered by urban trees in Adama city of central Ethiopia. The result of carbon sequestration and storage of Adama city was appeared higher than carbon assessment work conducted in cities such as Padua, Bolzano and Florence, Lisbon,Portugal, Zurich Switzerland (Crema 2008; Paoletti et al. 2011; Wälchli 2012). In the results current study the amount of carbon stored and sequestered in Adama urban trees was higher than result indicated in the study of Pace (Pace et al., 2018) regarding ecosystem services modeling for urban trees in Munich city of Germany; which was estimated to be 6225 ton and 214 tons per year respectively. Further more, the carbon storage and sequestration indicated in the current study were also compared with the study results presented for three cities of North America. Accordingly, the carbon storage and sequestration estimates of cities such as New York, Chicago and Jersey City were 1,225,200 and 38,400 tonn $C^{-y r}, 854,800$ and 40,100 tonn $C^{-y r}$ and 19,300 and 800 tonn $C^{-y r}$ respectively (Nowak and Crane, 2002). This comparison showed that the annual carbon storage and sequestration of the cites were higher than that of Adama city of Ethiopia except the annual carbon sequestration of Jersey city which was less than Adama city.

The carbon storage and sequestration results from this study were difficult to assess in terms of accuracy and to compare with other studies because of the use of different estimation methodologies, climatic condition, different species composition, and urban forest structures (Jo and McPherson 1995; Strohbach and Haase 2012).

The pollution removal indicated in this study was lower than the result reported form city of Baton Rouge which was 860 tons/year. In the work of Nowak et al. (2014) recently analyzed the effects of urban forests on air quality and human health in the United States, they found that in highly vegetated areas, trees can improve air quality by as much as $16 \%$ (Kroeger et.al 2014). Baumgardner et al. (2012) pointed out that around $2 \%$ of the ambient PM10 in Mexico city is removed from the study area. In a study carried out in the city of Barcelona (Spain), Barò et al. (2014) reported that urban forest services reduce PM10 air pollution by $2.66 \%$. Moreover, in the Mediterranean city of Tel-Aviv, Cohen et al. (2014) observed that an urban park significantly mitigated nitrogen oxides (NOx) and PM10 concentrations, with a greater removal rate being observed in winter, and increased tropospheric ozone levels during summer.

In this result, the amount of annual Volatile Organic Carbon (VOC) removal was lower than the report of study conducted in Scotlandville's trees which yearly produce 8.91 tons of monoterpene, 125.53 tons of isoprene, and produce 134.43 tons of volatile organic compounds (VOCs); that may contribute to ozone formation. (Nowak and Dwyer 2007; Nowak et al. 2014).

In Adama urban forest trees such as Acacia tortilis, Melia azedarach and Ficus elastica have higher potenatial evapotranspirationa and transpiration (Table 4). Similary, Xiao and McPherson (2016) reported that trees in urban areas can increase the return of runoff to the atmosphere through transpiration, providing associated air cooling benefits. Furthermore, according to the study of Gwynns Falls watershed in Baltimore indicated that heavily forested areas can reduce total runoff by as much as $26 \%$ and increase low-flow runoff by up to $13 \%$ compared with non-tree areas in existing land cover and land use conditions (Neville, 1996). Studies have also reported that tree cover over pervious surfaces reduced total runoff by as much as $40 \%$; while tree canopy cover over impervious surfaces had a limited effect on runoff.

The Adama urban forest interms of monetory value have presented in the result sction (Table 5). The outcome of current study was compared with the study conducted in city of Baton Rouge the annual monetory value of urban forest service were lower, interms of Carbon storage (\$6.2 million/year), Carbon sequestration (\$41.0 million) and pollution removal (\$ 1.1 million/year).

In general, this work has tried to quantify the ecosystem service value of Adama city of Ethiopia which will help for further urban forest development work and government intervention interms of policy and awareness creation. Further researches should be conducted the assess and evaluate the ecosystem service value of urban trees in several urban green insfrustures and comparing with different cities in the country. This will sensitize cities to learn and compute in urban forest development to enhance the ecosystem value of trees.

\section{Conclusions}


Urban trees and forests have positive effect on human health and well-being through improving air quality and reducing greenhouse gases, mainly through lowering air temperatures and energy use and through direct pollution removal and carbon sequestration. Although the current greening coverage and management practice is contributing significant amount of $\mathrm{CO}_{2}$ sequestration and pollutant removal, further greenery expansion in the city would help to have sustainabile urbanization trend in the city and its outskirts. The incoprporation of adequate tree coverage into the built-up environment and proper manamenet practices would expected to increase the pollutants and carbon absorbation.

Understanding the value of an urban forest can give decision makers a better understanding of urban tree management. Exotic tree and shrub species are the predominant vegetation of the Adama city. As a result, the higher carbon sequestration and pollutant removal were found with most introduced ornamental trees and shrubs. However, all trees and shrubs species are not positively contribute to the environmental remedy. Some species were found dversly affecting the environment due to the fact that significant amount of VOC emission and formation of pollutants.

These results provide baseline information for management recommendations to maximize the ecological benefits provided by trees. By understanding the effects of trees and forests on the atmospheric environment, urban forest managers and policy makers can decide on the policy and strategic planning of urban greening. Subsequently, it will help for designing appropriate and healthy vegetation structure in cities to improve air quality and consequently human health and well-being for current and future generations.

\section{Abbreviations}

SE: Standard Error; USD: US Dollar; yr: year; VOC:Volatile Organic Carbon; lb: pound (a unit of mass or weight); CO2: Carbon dioxide; ft2: Feet Squeare; DBH: Diameter at Breast Height; SO2: Sulfur dioxide; O3: Ozone; CO: Carbon mono oxide; NO2: Nitrogen dioxide; PM2.5: Particulate Matter less than 2.5 microns.

\section{Declarations}

\section{Acknowledgment}

The authors acknowledge the experts of Adama city urban greening and beautification department (Mr. Abu Regasa, Mr. Adugna Muleta, Mr. Girma Godana, and Mr. Yadesa Kacha) for their assistance in facilitating the fieldwork. Also the authors are grateful to Dr. Mesfin Asefa a Mayor of Adama city administration and as well as Wuhan University of Technology, China for financial and other necessary support during our study.

\section{Author's Contributions}

Mr. Hingabu Hordofa: Contributed in designing the research idea, data collection, report writing and data analysis and guiding the overall paper work:

Mr. Ararsa Derese: Participated in data analysis, interpretation and report writing:

Mr. Tikabo Gebreyesus: Participated in data interpretation and edited language:

Dr. Fekadu Fufa: Participated in designing method and sturucturing report:

Prof. Shaoxian Song: Participated in designing method, sturucturing report and guiding the overall paper work.

\section{Funding}

This work was supported by the Adama City Administration [\$1500]; Wuhan University of Technology [\$1000] are greatly acknowledged. 


\section{Availability of data and materials}

The data set generated for the study area is available from the corresponding author on reasonable request.

\section{Ethics approval and consent to participate}

The subject has no ethical risk.

\section{Consent for publication}

The subject matter has no ethical risk.

\section{Computing interest}

The authors declares that they have no competing interests.

\section{References}

Baró, F., Chaparro, L., Gómez-Baggethun, E., Langemeyer, J., Nowak, D. J., \& Terradas, J. (2014). Assessing ecosystem services provided by urban forests in relation to air quality and climate change mitigation policies in Barcelona, Spain. Ambio, 43, 466479.

Baumgardner, D., Varela, S., Escobedo, F. J., Chacalo, A., \& Ochoa, C. (2012). The role of a peri-urban forest on air quality improvement in the Mexico City megalopolis. Environmental Pollution, 163, 174-183.

Central Statistical Authority (CSA). (2007). Report. Retrieved 22 January 2018, from http://www.csa. gov.et/censusreport/complete-report/census-2007\#

Cohen, P., Potchter, O., \& Schnell, I. (2014). The impact of an urban park on air pollution and noise levels in the Mediterranean city of Tel-Aviv, Israel. Environmental Pollution, 195, 73-83.

Crema, S. (2008). Urban forestry e stima del carbonio: analisi di linee guida e calcolo in zona urbana come applicazione ed opportunità per l'Università di Padova.

Forrest, M., Konijnendijk, C. C., \& Randrup, T. B. (1999). COST action E12 research and development in urban forestry in Europe. TUM.

Girma, Y., Terefe, H., Pauleit, S., \& Kindu, M. (2019). Urban green spaces supply in rapidly urbanizing countries: The case of Sebeta Town, Ethiopia. Remote Sensing Applications: Society and Environment, 13, 138-149.

i-Tree-Tools for Assessing and Managing Community Forests [Internet]. 2010. Washington (DC): USDA Forest Service; [cited 2010 Oct 15]. Available from: http://www.itreetools. org/eco/resources/UFORE\%20Model\%20FAQs.pdf.

Jo, H. K., \& McPherson, G. E. (1995). Carbon storage and flux in urban residential greenspace. Journal of Environmental Management, 45(2), 109-133.

Kroeger, T., Escobedo, F. J., Hernandez, J. L., Varela, S., Delphin, S., Fisher, J. R., \& Waldron, J. (2014). Reforestation as a novel abatement and compliance measure for ground-level ozone. Proceedings of the National Academy of Sciences, 111(40), E4204-E4213.

McPherson, E. G. (2010). Selecting reference cities for i-Tree Streets. Arboriculture and Urban Forestry 36 (5): 230-240, 36(5), 230-240. 
Mpofu, T. P. Z. (2013). Environmental challenges of urbanization: A case study for open green space management. Research Journal of Agricultural and Environmental Management, 2(4), 105-110.

Neville, L. R., 1996, Urban Watershed Management: The Role of Vegetation, Ph.D. Discussions., SUNY College of Environmental Science and Forestry, Syracuse, NY.

Nowak, D. J., Crane, D. E., Stevens, J. C., Hoehn, R. E., Walton, J. T., \& Bond, J. (2008). A ground-based method of assessing urban forest structure and ecosystem services. Aboriculture \& Urban Forestry. 34 (6): 347-358., 34(6).

Nowak, D. J., \& Crane, D. E. (2002). Carbon storage and sequestration by urban trees in the USA. Environmental pollution, 116(3), 381-389.

Nowak, D. J., Hirabayashi, S., Bodine, A., \& Greenfield, E. (2014). Tree and forest effects on air quality and human health in the United States. Environmental pollution, 193, 119-129.

Pace, R., Biber, P., Pretzsch, H., \& Grote, R. (2018). Modeling ecosystem services for park trees: Sensitivity of i-tree eco simulations to light exposure and tree species classification. Forests, 9(2), 1-18.

Paoletti, E., Bardelli, T., Giovannini, G., \& Pecchioli, L. (2011). Air quality impact of an urban park over time. Procedia Environmental Sciences, 4(0), 10-6.

Rydin, Y., Bleahu, A., Davies, M., Dávila, J. D., Friel, S., De Grandis, G., ... \& Lai, K. M. (2012). Shaping cities for health: complexity and the planning of urban environments in the 21st century. The lancet, 379(9831), 2079-2108.

Seto, K. C., \& Shepherd, J. M. (2009). Global urban land-use trends and climate impacts. Current Opinion in Environmental Sustainability, 1(1), 89-95.

Steenberg, J. W. N., Millward, A. A., Nowak, D. J., Robinson, P. J., \& Ellis, A. (2016). Forecasting Urban Forest Ecosystem Structure, Function, and Vulnerability. Environmental Management, June 2018.

Strohbach, M. W., \& Haase, D. (2012). Above-ground carbon storage by urban trees in Leipzig, Germany: Analysis of patterns in a European city. Landscape and Urban Planning, 104(1), 95-104.

Terfa, B. K., Chen, N., Zhang, X., \& Niyogi, D. (2020). Spatial configuration and extent explains the urban heat mitigation potential due to green spaces: Analysis over Addis Ababa, Ethiopia. Remote Sensing, 12(18).

Wälchli, G. (2012). Ökosystemdienstleistungen als ökonomische Strategie? i-Tree: ein Instrument für die Wertermittlung von Stadtbäumen Zusammenfassung [dissertation-in German]. Wädenswil: Zürcher Hochschule für Angewandte

Wissenschaften.

\section{Figures}




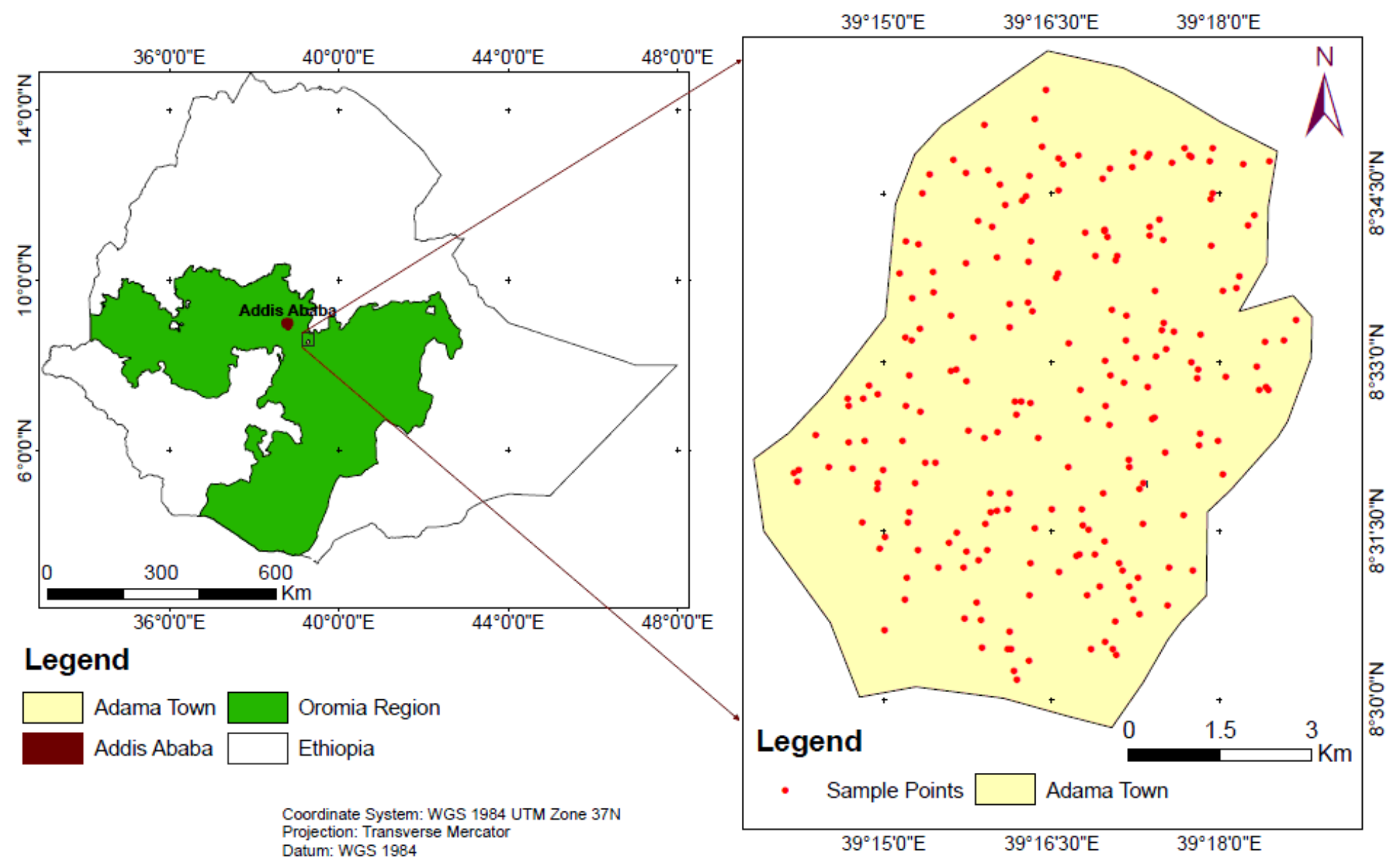

Figure 1

Location map of the study area.

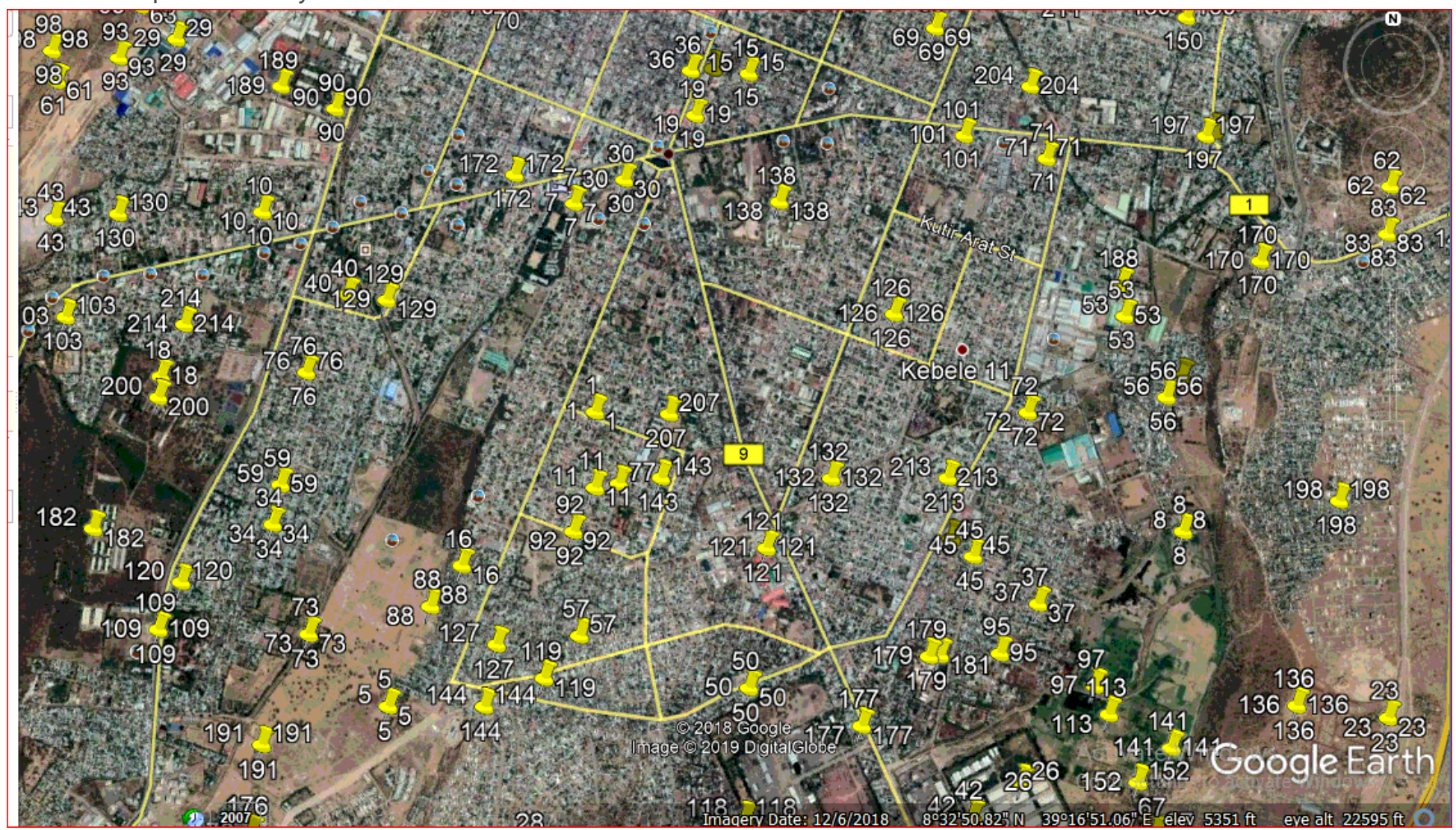


Figure 2

Sample plots (highlighted yellow) distribution randomly within the project site based on the standard of the i-tree eco Model

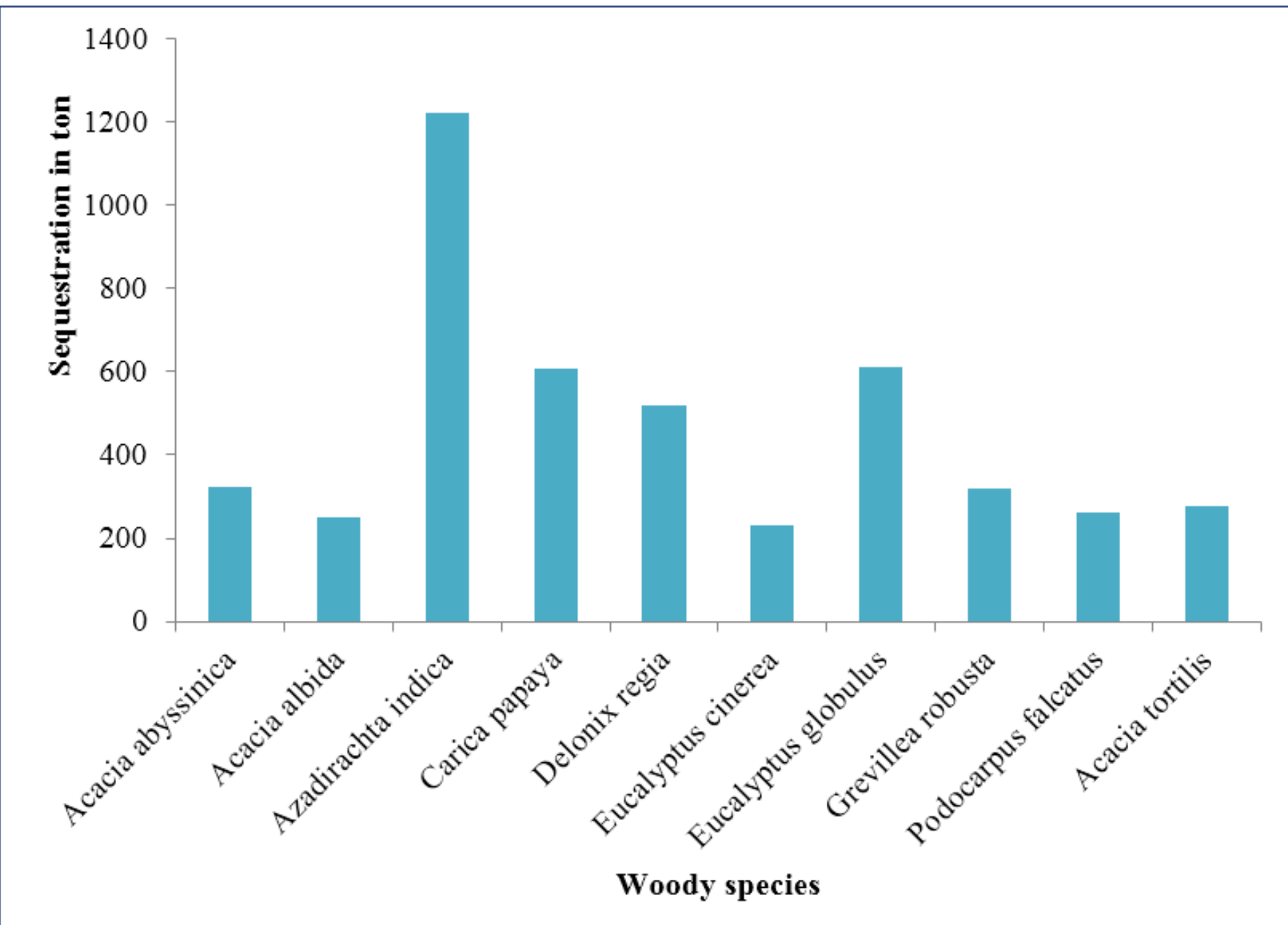

Figure 3

Estimated annual gross carbon sequestration (points) and value (bars) by urban tree species of Adama city

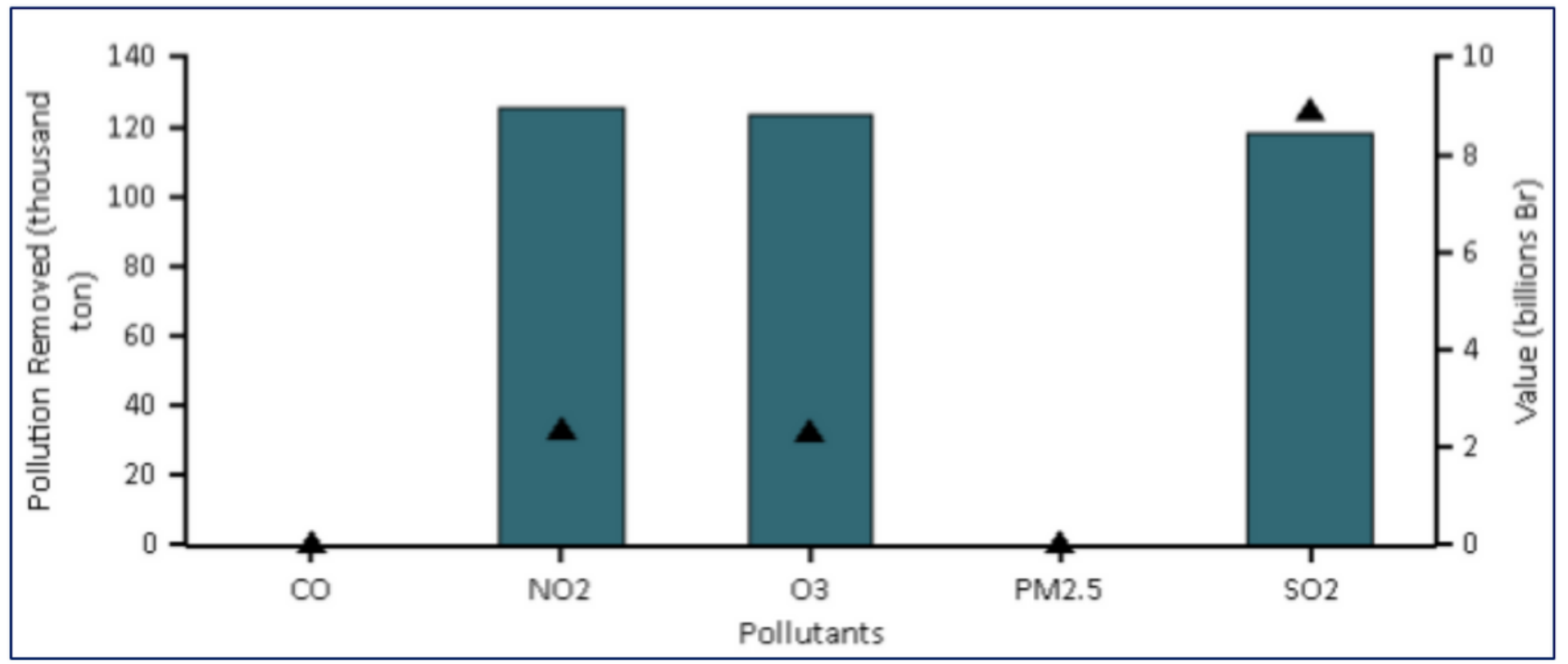




\section{Figure 4}

Annual pollution removal (points) and value (bars) by urban trees of Adama city 